GEOLOGICAL SURVEY CIRCULAR 225

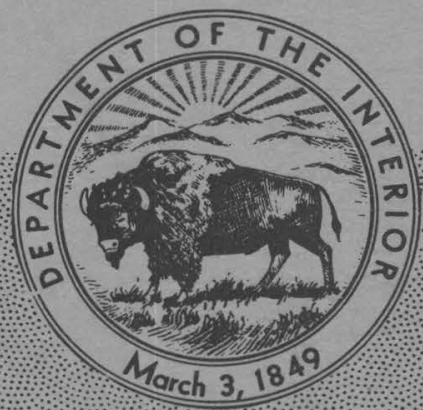

GEOCHEMICAL ASSOCIATION OF

NIOBIUM (COLUMBIUM) AND TITANIUM

AND ITS GEOLOGICAL AND

ECONOMIC SIGNIFICANCE

By Michael Fleischer, K. J. Murata, Janet D. Fletcher, and Perry F. Narten

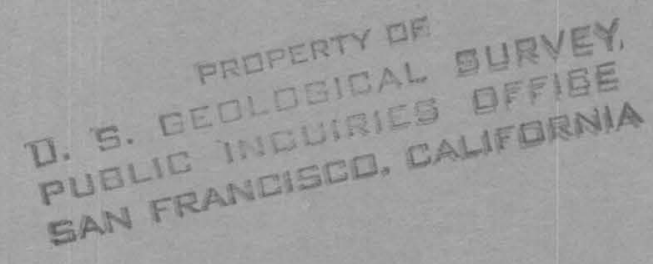



UNITED STATES DEPARTMENT OF THE INTERIOR

Oscar L. Chapman, Secretary

GEOLOGICAL SURVEY

W. E. Wrather, Director

GEOLOGICAL SURVEY CIRCULAR 225

\section{GEOCHEMICAL ASSOCIATION OF NIOBIUM (COLUMBIUM) AND TITANIUM AND ITS GEOLOGICAL AND ECONOMIC SIGNIFICANCE}

By Michael Fleischer, K. J. Murata, Janet D. Fletcher, and Perry F. Narten 


\title{
GEOCHEMICAL ASSOCIATION OF NIOBIUM (COLUMBIUM) AND TITANIUM AND ITS GEOLOGICAL AND ECONOMIC SIGNIFICANCE
}

\author{
CONTENTS
}

Fage

Fage

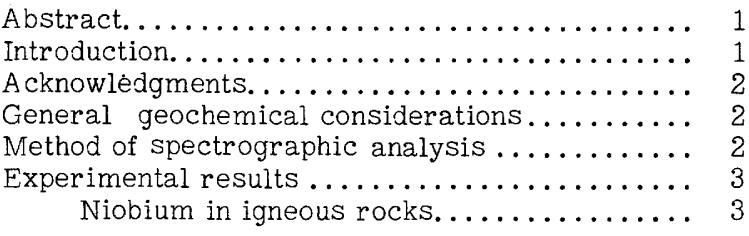

Experimental results--Continued

Niobium in bauxite............... 3

Niobium in byproducts of bauxite plants.... 7

Niobium in titanium minerals......... 8

Fossibility of recovery of niobium from Arkansas

bauxite and from titanium minerals........ 8

Literature cited.................... 9

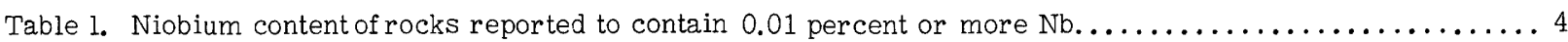

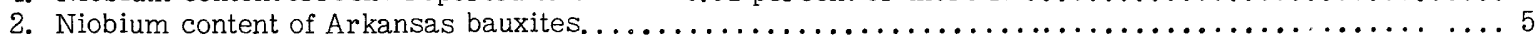

3. Niobium content of products of bauxite treatment at the Hurricane Creek plant,

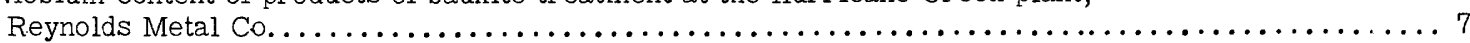

4. Analyses of titanium - and iron-rich concentrates from black sands from the Hurricane Creek

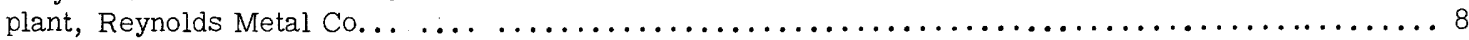

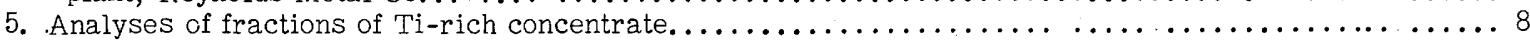

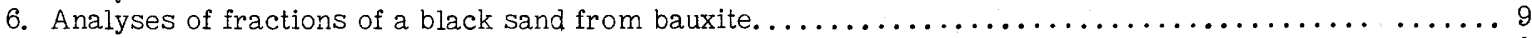

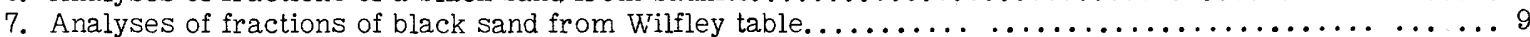

8. Niobium content of titanium minerals. . . . . . . . . . . . . . . . . . . . . . . . . . . .

\section{ABSTRACT}

Niobium in rocks occurs in highest concentrations in granitic pegmatites and in alkalic rocks such as the nepheline syenites. It occurs commonly as a substituent in titanium minerals. Weathering of alkalic rocks produces bauxite enriched in niobium. Analyses show bauxite from Arkansas to contain an average of 0.05 percent $\mathrm{Nb}$. The niobium present in the Arkansas bauxite processed annually is equal in amount to about 80 percent of that imported annually by the United States. Fractionation of black sand from Arkansas bauxite shows the niobium to be concentrated chiefly in an ilmenite fraction containing more than 40 percent $\mathrm{TiC}_{2}$ and as much as 0.86 percent $\mathrm{Nb}$.

Analyses of titanium minerals from many sources show the presence of niobium, the amount present varying with the type of rock in which the minerals occur. Minerals from alkalic rocks and from granitic pegmatites are highest in niobium content.

Metallurgical research is needed, especially on the possibility of recovering ni bium and titanium from chlorination processes.

\section{INTR.ODUCTION}

Niobium (columbium) has recently become important in the manufacture of certain high-temperature and non-creep steels. The United States imported more than 1-1/2 million pounds of niobium ore (concentrates) in 1949 (Clark, 1951); $;^{1}$ domestic production was very small. The world production has come from granitic pegmatites and as a byproduct of the recovery of cassiterite from placers derived from granitic rocks.

Early in 1951 the Geological Survey undertook a search for new sources of niobium. Fortunately the general pattern of the geochemical behavior of niobium was fairly well known from an earlier summary of the literature (Fleischer and Harder, 1945) and from the comprehensive researches of Rankama (1948). From these it was possible to select for further study several types of material in which niobium might be present in concentrations sufficient to make them of interest as source materials.

Those selected as the most promising types of material were (1) alkalic rocks, especially nepheline syenites; (2) bauxites derived from alkalic rocks; (3) titanium minerals and ores; (4) zirconium minerals and ores; (5) tungsten minerals and ores; and (6) tin minerals and ores. The present report is a preliminary account of work on the first three. Niobium has been found in concentrations sufficiently high to justify research on the metallurgical processes for its separation and recovery. The search for new sources of niobium will be continued, and it is hoped that this report will stimulate others to begin the required metallurgical research.

${ }^{1}$ See Literature cited 


\section{ACKNOWLEDGMENTS}

We are indebted to our colleagues M. K. Carron, J. I. Dinnin, and Leonard Shapiro, who made chemical analyses; Elizabeth L. Hufschmidt, J. C. Rabbitt, and H. J. Rose, Jr., who made spectrographic analyses; and Jewell J. Glass and Marie L. Lindberg, who made mineralogical separations. R. F. Bryson, E. F. Kaiser, J. J. Norton, and W. T. Fecora, of the Geological Survey, contributed advice as to the selection of samples for analysis.

Samples for analysis were contributed by the following companies, who kindly granted permission to publish the results obtained. Alcoa Mining Co., American Cyanamid Co., Dulin Bauxite Co., Consolidated Chemical Industries, Dulin Bauxite Co., E. I. du Font de Nemours Co., The Glidden Co., National Lead Co., New Jersey Zinc Co., and Ventures, Ltd.

\section{CENERAL GEOCHEMICAL CONSIDERATIONS}

Nrobium is a chemical element with atomic number 41 and atomic weight 92.91. It belongs to the fifth group of the periodic table and is quinquevalent in most of its compounds. Niobium is a rare element; Rankama (1948, pp. 48-52) estimates its abundance in igneous rocks to be 0.0024 percent, which would make it about thirty-first in abundance of the elements.

The empirical ionic radius of niobium is given as 0.69A. (Ahrens, 1952), not very different from those of magnesium (0.66A.) and ferrous iron (0.74A.). The valence of niobium, however, is so much higher that one would expect that magnesium and iron minerals formed in the early stages of magmatic crystallization would not contain much niobium. This expectation has been verified experimentally. As crystallization of igneous rocks proceeds, niobium is perferentially concentrated in the residual magmas as shown by Goldschmidt (1937) and by Rankama (1948). According to Rankama, the igneous rocks of highest niobium content are the granites $(0.0021$ percent), the syenites ( 0.0035 percent), and the nepheline syenites (0.031 percent). Of all igneous rocks, therefore, the nepheline syenites and similar alkalic rocks contain more than 10 times the concentration of other rocks and appear to be the most promising for further study.

Goldschmidt (1937, p. 667) points out that niobium would be expected, considering its ionic potential, to be concentrated during weathering processes; he states that for bauxite the factor of concentration is 4 to 5 as compared with the parent rock. Because the nepheline syenites are rocks high in niobium, bauxites derived from them should be particularly rich in niobium. This has now been tested and verified in the laboratory of the Geological Survey and a summary of the results on Arkansas bauxites has been published in a recent paper (Gordon and Murata, 1952). The study is being pursued further, particularly to learn the mode of occurrence of the niobium and its distribution in the bauxite district and among the minerals of the bauxite.

One would expect that niobium would occur as a substituent for elements of high valence having ionic radii close to $0.60 \mathrm{~A}$.' These include quinquevalent
Ta (0.68A.), quadrivalent Ti (0.68A.), Zr (0.79A.), Sn (0.71A.), and Mo (0.62A.), and sexivalent $\mathrm{W}(0.62 \mathrm{~A}$.). . This is confirmed by experimental data except for molybdenum. The very close association of niobium and tantalum is well known. Rankama (1948, pp. 48-52) points out that these elements are separable in nature and that the $\mathrm{Nb}$ :Ta ratio, which averages 11.4 , is very much higher (384) in nepheline syenites. The association of niobium with titanium has been shown by the work of Hevesy, Alexander, and Würstiin (1929), Kunitz (1936), Borowsky and Blochin (1937), Panteleleev (1938), and Rankama (1948). The niobium content of titanium minerals, with particular attention to their geological environment, is also under investigation in the Geological Survey laboratories. A summary of the results up to now, including data from the literature, is given below. Studies of the association of niobium with tungsten, tin, zirconium, and molybdenum will be reported later.

\section{METHCD OF SFECTROGRAPHIC ANALYSIS}

The spectrographic analyses were made under the following conditions:

Excitation: 220-volt ballasted d-c arc, run at 15.5 a. Arc gap maintained at $3.5 \mathrm{~mm}$ throughout the burning period. Arc image focussed on the slit at 5.5 magnification, and light from the central $2 \mathrm{~mm}$ part allowed to enter the spectrograph.

Spectrograph: Wadsworth-mounting type of grating spectrograph with dispersion of $5 \mathrm{~A} / \mathrm{mm}$ in the first order.

Wavelength range covered: $2,230-4,730 \mathrm{~A}$ in the first order. Such a wide range is unnecessary for analyses solely for $\mathrm{Nb}$, but was recorded so that the spectrograms would be available for future study of other elements.

Electrodes: High-purity graphite rods, 1/4 in. diameter, with thin-walled cavity as described by Myers (1951); used as the anode.

Flate: Eastman III-O, developed at $20^{\circ} \mathrm{C}$ for $5 \mathrm{~min}$ in $\mathrm{DK}-50$ developer.

Flate calibration: Method of Dieke and Crosswhite (1943). Iron lines present in spectra of a quartz-microcline mixture containing 1 percent $\mathrm{Fe}_{2} \mathrm{O}_{3}$ (matrix of comparison standards) were used.

Microphotometer: Frojection comparator-microphotometer employing a scanning slit at the plate.

Nb lines used: 3163.40 and 3194.98A. Limit of detection, 0.01 percent in the samples as analyzed.

Analytical curves were established by means of a set of standards containing known concentrations of $\mathrm{Nb}_{2} \mathrm{O}_{5}$ and $\mathrm{Ta}_{2} \mathrm{O}_{5}$ (high-purity oxides) in a matrix consisting of 60 parts of quartz, 40 parts of microcline, and 1 part of $\mathrm{Fe}_{2} \mathrm{O}_{3}, 25-\mathrm{mg}$ portions being arced to 
completion. The standards were made by successive dilutions to contain $1.00,0.464,0.215,0.100,0.0464$, $0.0215 \ldots . .0 .00100$ percent $\mathrm{Nb}$ and $\mathrm{Ta}$. No internal standard was used. The quartz-feldspar-iron oxide matrix will hereafter be referred to as the pegmatite base.

All rocks and minerals were first crushed, quar tered, and ground in agate mortars to pass 150-mesh silk bolting cloth. Bauxites and clays were then ignited at $900^{\circ} \mathrm{C}$ and the loss in weight noted so that the final percentage of $\mathrm{Nb}$ could be calculated to the original, unignited state.

In order to analyze materials of greatly different chemical composition by means of the pegmatite-base standards, the samples were further treated in such a way as to make their composition more nearly that of the standards. Igneous rocks were mixed with onehalf their weight of pure quartz. All other materials were mixed with an equal weight of a powder composed of 95 percent quartz and 5 percent $\mathrm{Na}_{2} \mathrm{CO}_{3}$.

The prepared samples were then analyzed by arcing to completion duplicate $25-\mathrm{mg}$ portions. All samples showing 0.05 percent or more of $\mathrm{Nb}$ were next diluted with sufficient pegmatite base so that their reanalysis would be done at a concentration level of about 0.015 percent $\mathrm{Nb}$. This practice resulted in greater accuracy for samples high in $\mathrm{Nb}$ because these (in the diluted state) closely approached the comparison standards in composition. As a test of the reproducibility of the method, a number of samples were analyzed in duplicate on several plates on different days. Considering the mean of the duplicate on each plate as a determination, the results were within \pm 10 percent of the average of all determinations.

To date, only a few samples have been analyzed chemically, and we are indebted to J. I. Dinnin and M. K. Carron, of the Geological Survey, for the chemical results tabulated below.

Fercent $\mathrm{Nb}$

Spectrographic Chemical

\begin{tabular}{|c|c|c|}
\hline Bauxite--_-_--- & 0.053 & 0.05 \\
\hline Bauxite---n---- & .050 & .03 \\
\hline Brookite --.---- & 2.4 & 2.7 \\
\hline Wolframite------ & 1.3 & 1.2 \\
\hline Lepidolite--_-_-_- & 1. 1 & 1.2 \\
\hline
\end{tabular}

\section{EXFERIMENTAL RESULTS}

\section{Niobium in igneous rocks}

The average content of niobium in various types of igneous rocks was deter mined by Rankama (1948) by the analysis of 78 samples with the following results:

Fercent Nb (average)

Anor thosites and dunites-......-.

0.00003

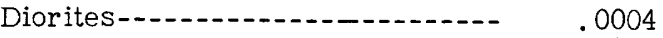

Eclogites-1...-. .0004

Basic alkalic rocks-_._-_._-.... .0014

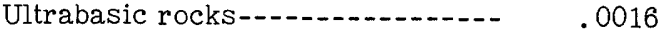

Gabbros-1.-. 0019

Granites---1.0.-.021

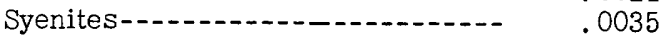

Nepheline syenites-_.-. .031
Our studies have confirmed the relatively high niobium content of nepheline syenites and related rocks and have shown that high niobium content is particularly characteristic of those alkalic rocks with which are associated the remarkable masses of crystalline $\mathrm{CaCO}_{3}$ generally referred to as "carbonatites." As further study of these rocks, particularly of the mode of occurrence of the niobium in them, is under way, we shall reserve detailed discussion and merely present the data available on all rocks that have been reported to contain as much as 0.01 percent $\mathrm{Nb}$. These data are assembled in table 1. Nearly all the 52 rocks listed are nepheline syenites or related rocks, with only a few rocks of granitic composition and a. few mafic rocks that are associated with alkalic rocks. No quantitative data are yet available on the distribution of niobium among the minerals of these rocks, although it is known that the niobium is largely concentrated in such titanium minerals as rutile, ilmenite, perovskite, and sphene. Analyses of these minerals separated from the abovementioned or from similar rocks are listed in table 8 and are discussed below under the heading "Niobium content of titanium minerals. "Fart of the niobium in some of these rocks is present in zirconium minerals such as zircon, eudialyte, and catapleiite, and part is in some rocks as the niobium minerals pyrochlore (alkalic rocks) and columbite or microlite (granitic rocks).

\section{Niobium in bauxites}

We have extended the work of Gordon and Murata (1952), whose analyses of 14 bauxites and bauxitic clays from Arkansas showed a minimum content of 0.02 percent $\mathrm{Nb}$, a maximum content of 0.1 percent $\mathrm{Nb}$, and an average content of 0.05 percent $\mathrm{Nb}$. Table 2 lists these analyses and those of 32 additional samples which confirm the earlier results. Further work is in progress to determine how the niobium content varies in different parts and types of bauxite deposits in Arkansas and to deter mine the dis tribution of niobium among the minerals of the bauxite.

Analyses have also been made by the Geological Survey of many samples of bauxite derived from rocks other than alkalic rocks, including material derived from basaltic rocks, gneisses, and limestones. These samples have much lower contents of niobium; none was found that contained as much as 0.01 percent $\mathrm{Nb}$. The samples include 5 lateritic bauxites from Cregon, collected by J. W. Hosterman; 28 high-alumina clays from Idaho and Washington, collected by I. G. Sohn and J. W. Hosterman; 3 bauxites from Surinam, Dutch Guiana, kindly furnished by Aluminum $\mathrm{Co}$. of America and American Cyanamid Co.; and 1 bauxite from Berbice, British Guiana, kindly furnished by American Cyanamid $\mathrm{Co}$. Rankama (1948) reports 0.004 percent $\mathrm{Nb}$ in bauxites from Melegesbanya, near Gant, Hungary, and from Rock Run, Ala. It is of interest to note (table 3) that samples of red mud from treatment of Surinam and Jamaica bauxites both contained 0.02 percent $\mathrm{Nb}$, which suggests that these bauxites contain some thousandths of a percent of $\mathrm{Nb}$.

We hope to analyze bauxites which are from localities, other than Arkansas, where the bauxite 
Table 1.--Niobium content of rocks reported to contain 0.01 percent or more $\mathrm{Nb}$

\begin{tabular}{|c|c|c|c|c|c|c|}
\hline & Locality & $\begin{array}{l}\text { Number of } \\
\text { samples }\end{array}$ & Percent $\mathrm{Nb}$ & Type of rock & Collector & Analyst \\
\hline 1 & $\begin{array}{l}\text { Arkansas: Pulaski and } \\
\text { Saline Counties. }\end{array}$ & 9 & $0.016-0.035$ & Nepheline syenite....- & $\begin{array}{l}\text { M. Gordon, } \\
\text { R. P. Bryson. }\end{array}$ & $\begin{array}{l}\text { K. J. Murata, } \\
\text { H. J. Rose, Jr. }\end{array}$ \\
\hline 2 & Arkansas, Saline County-..... & 1 & .04 & Tinguaite dike_-_-_-- & W. T. Holser.-. & K. J. Murata. \\
\hline 3 & Arkansas, Magnet Cove & 5 & $.02-.06$ & Alkalic rocks-_----.- & W. T. Pecora---- & $\begin{array}{l}\text { K. J. Murata, } \\
\text { H. J. Rose, Jr. }\end{array}$ \\
\hline 4 & $\begin{array}{l}\text { Arkansas, Potash Sulfur } \\
\text { Springs. }\end{array}$ & 6 & $\{.05, .15, .27$ & 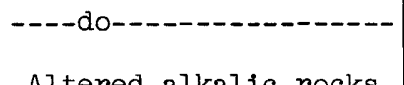 & $\left\{\begin{array}{l}\text { W. T. Pecora, } \\
\text { E. Ingerson. }\end{array}\right.$ & $\begin{array}{l}\text { J. D. Fletcher, } \\
\text { K. J. Murata. }\end{array}$ \\
\hline 5 & Colorado, Iron Hill_....... & 11 & $2.7,3.0$ & $\begin{array}{l}\text { Altered alkallc rocks- } \\
\text { Alkalic rocks }\end{array}$ & V. R. Wilmarth--- & J. D. Fletcher. \\
\hline$\overline{6}$ & Idsho, Lemh1 County---n & 2 & $.01, .03$ & Granite pegmatite----- & W. A. Roberts--- & H. J. Rose, Jr. \\
\hline 7 & New Hampshire, Bartlett_....- & 1 & .02 & Granite $\ldots \ldots$ & W. T. Holser--- & K. J. Murata. \\
\hline 8 & New Jersey, Beemerville-...-- & 1 & .01 & Nepheline syenite._.-.- & - n- - do- - - - & Do. \\
\hline 9 & New Mexico, Wind Mountains--- & 1 & .02 & ---- do-n-- & 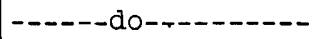 & Do. \\
\hline 10 & 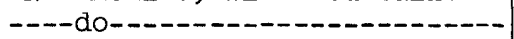 & $\overline{1}$ & .34 & Eudialyte syenite-.-.-- & 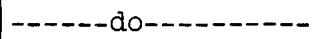 & Do. \\
\hline 11 & New Mexico, Black Mountains-- & $\bar{I}$ & .03 & Nepheline syenite..... & - - - - do $-1-----$ & Do. \\
\hline 12 & New Mexico, Jemez Mountains-- & 2 & .01 & Rhyolites--- & C. S. Ross---- & Do. \\
\hline 13 & Texas, Sierra Diablo_-_...- & 4 & $.05-.2$ & Alkalic rocks & A. Slaughter--- & J. C. Rabbitt. \\
\hline 14 & Greenland, Julienahaab dist.- & 2 & a.32, .21 & Nepheline syenite....... & $--\cdots-n-1--\cdots$ & Ussing (1912) \\
\hline 15 & Sweden, Gellaberg, Skane-...-- & 1 & .017 & Feldspar basalt------- & $----\cdots-------$ & Rankama (1948). \\
\hline 16 & Germany, Hammer & 1 & .02 & Phonolite & $---\cdots------\cdots--$ & Do. \\
\hline 17 & Portugal, Serrade Monchique-- & 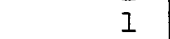 & .04 & Nepheline syenite.....- & $------1--m-\infty$ & Rankama (1948). \\
\hline 18 & U.S.S.R., Mariupol dist..._- & 7 & $.02-.08$ & 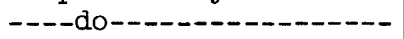 & ------------ & Morozewicz (1930). \\
\hline 19 & U.S.S.R., Kola Peninsula_---- & 1 & .11 & $\begin{array}{l}\text { Titanomagnetite } \\
\text { olivinite. }\end{array}$ & ----------- & Rankama (1948). \\
\hline
\end{tabular}

aThe accuracy of these old chemical analyses is questionable. 
Table 2 --Niobium content of Arkansas bauxite

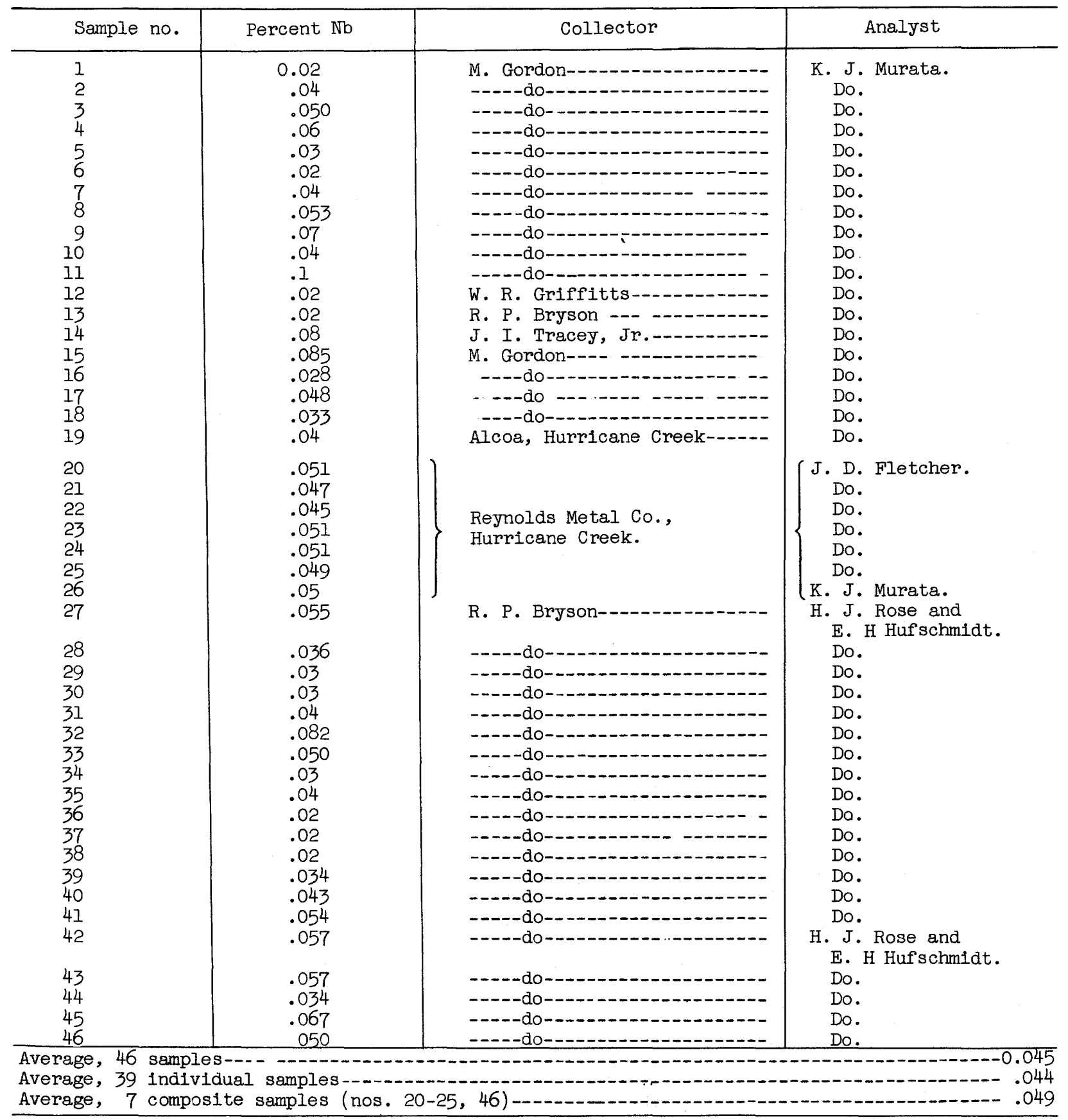

Descriptions of samples:

1. Dark reddish-brown to black bauxite pebbles filling channels in the lower bauxite bed in

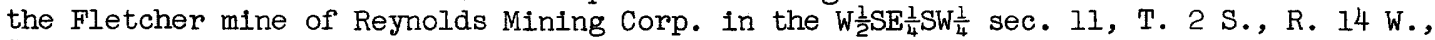
Saline County.

2. Oxidized ferruginous granitic-textured bauxite from a weathered outcrop in the Pruden mine, Alcoa Mining Co., $\mathrm{NE}_{4}^{1} \mathrm{SW}_{\frac{1}{4}} \mathrm{sec} .16, \mathrm{~T} .2 \mathrm{~S} ., \mathrm{R} .14 \mathrm{~W} .$, Saline County.

3. Red bauxite with black pisolites ("birds-eye ore") from mining face in the west part of the Section 16 mine, Alcoa Mining Co., SE $\frac{1}{4}$ SW $\frac{1}{4}$ sec. 16, T. 2 S., R. 14 W, Saline County.

4. Granitic-textured bauxite ("sponge ore") block from along company road in Middle Maud mine, Alcoa Mining Co., in SW $\frac{1}{4} \mathrm{SE}_{4}^{1}$ sec. 22, T. 2 S., R. 14 W., Saline County.

5. Poorly pisolitic bauxite containing fine siderite, from U. S. Bur. Mines drill hole 3-019, depth 267 feet, South Ironton deposit, W.A. Dreher property, in the NW $\frac{1}{4} \mathrm{SE}_{\frac{1}{4}} \mathrm{sec}$. 14 , T. I S., R. $12 \mathrm{~W}$., near Ironton, Pulaski County. 
Descriptions of samples, table 2--Continued

6. Pisolitic bauxite hardcap with fluid pisolites from U. S. Bur. Mines drill hole 6-127B,

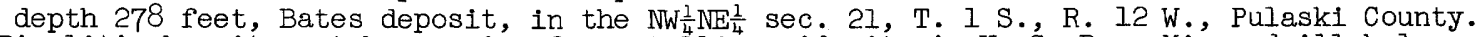

7. Pisolitic bauxite cut by a vein of crystalline siderite in U. S. Bur. Mines drill hole 16-048, depth 455.2 feet, in the East Bauxite deposit, International Paper Co. property, in the $\mathrm{SE} \frac{1}{4} \mathrm{sec}$. 31, T. 2 S., R. $13 \mathrm{~W}$., Saline County.

8. Poorly pisolitic bauxite containing siderite and chlorite, from U. S. Bur. Mines drill hole 16-052, depth 473.0 to 473.1 feet, East Bauxite deposit, International Paper Co. property, $\mathrm{SE} \frac{1}{4}$ sec. 31, T. 2 S., R. 14 W., Saline County.

9. Poorly pisolitic siliceous bauxite from U. S. Bur. Mines drill hole 16-052, depth 451.9 to 452.2 feet.

10. Tannish-gray bauxitic underclay from U. S. Bur. Mines drill hole 16-052, depth 480.5 to 480.6 feet.

11. Fragmental kaolinitic underclay from U. S. Bur. Mines drill hole 16-052, depth 488 feet.

12. Type III bauxite deposit. Transported pebbly bauxite with gibbsitic to kaolinitic matrix, from east face of the Harley pit mine of Dulin Bauxite Co., SE $\frac{1}{4} \mathrm{SE} \frac{1}{4}$, sec. 24, T. 1 N., R. 12 W., Pulaski County.

13. Type III bauxite deposit. Cross-bedded bauxite from ore body in Reichart shaft mine, NW $\frac{1}{4}$ SW $\frac{1}{4}$, sec. 2, T. 1 S., R. 12 W., Pulaski County.

14. Type IV bauxite deposit. Transported light-tan bauxite rubble, at or near top of upper bauxite bed, near middle of west wall of the Midwest Pit mine of Midwest Mines Co. in the $E_{\frac{1}{2}} \mathrm{NE}_{\frac{1}{4}} \mathrm{NE}_{\frac{1}{4}}$, sec. 24 , T. 2 S., R. 14 W., Saline County.

15. Harris deposits near Bryant.

16. Ratcliffe mine, Pulaski County.

17. Stuckey pit at Bauxite.

18. Section 26 mine near Bauxite.

19. Hurricane Creek plant.

20. Reynolds. Month-end composite, July, August, September 1947.

21. Reynolds. Month-end composite, June, July, August 1948.

22. Reynolds. Month-end October 1949.

23. Reynolds. Month-end April 1950.

24. Reynolds. Month-end April 1951.

25. Reynolds. Month-end November 1951.

26. Reynolds. Bauxite from Hurricane Creek plant.

27. Bauxitic clay (from Consolidated Chemical Industries plant stockpile), Bierman mine, Pulaski County.

28. Bauxite (from plant stockpile), Bierman mine.

29. Bauxite. Monthly composite, Berry-Mayhan mine; SW $\frac{1}{4} N E \frac{1}{4}$, sec..2, T. I S., R. 12 W., Pulaski County. American Cyanamid Co., Berger Plant.

30. Bauxite, low-iron type (raw composite) Dan Rauch mine, $\mathrm{SE} \frac{1}{4} \mathrm{NE} \frac{1}{4}$, sec. 9, T. I S., R. 12 W., Pulaski County. American Cyanamid Co.

31. Bauxite, calcined product from blend of bauxite, Dixie mine, SW $\frac{1}{4} \mathrm{SW} \frac{1}{4}, \mathrm{sec} .36, \mathrm{~T}$. I N., R. 12 W., Pulaski County, and BC-400 mine, $\mathrm{SE} \frac{1}{4} \mathrm{NW} \frac{1}{4}, \mathrm{sec} .31, \mathrm{~T} .2 \mathrm{~S} . \mathrm{R}$. 13 W., Saline County. Dulin Bauxite Co.

32. Bauxite, high organic content typical; part granitic and part pisolitic. Bertha Extn. mine, $\mathrm{SE} \frac{1}{4}$, sec. 27, T. 2 S., R. 14 W., Saline County. Alcoa Mining Co.

33. Bauxite, granitic, grab sample from conveyor belt. Nielson Underground $\cdot \mathrm{mine}$, NW $\frac{1}{4} N W \frac{1}{4}$, sec. 26, T. 2 S., R. 14 W., Saline County. Alcoa Mining Co.

34. Bauxite, grab sample by shaft, BC-400 mine, SE $\frac{1}{4} N W \frac{1}{4}$, sec. 31, T. 2 S., R. 13 W., Saline County. Dulin Bauxite Co.

35. Bauxite(?) from thin bed in Wilcox formation (core sample), middle of sec. 28, T. 2 S., R. 14 W., Saline County. Alcoa Mining Co.

36. Bauxite, auger drill sample, upper 6 feet; Lewis mine, NW $\frac{1}{4} N W \frac{1}{4}$, sec. 9, T. 1 S., R. 12 W., Pulaski County. American Cyanamid Co.

37. Bauxite, auger drill sample, 6 to 12 feet; Lewis mine, NW $\frac{1}{4} N W \frac{1}{4}$, sec. 9, T. 1 S., R. 12 W., Pulaski County. American Cyanamid Co.

38. Bauxite, auger drill sample, 12 to 18 feet; Lewis mine, NW $\frac{1}{4} N W \frac{1}{4}$, sec. 9, T. I S., R. 12 W., Pulaski County. American Cyanamid Co.

39. Bauxite, daily mine production. Harris mine, $\mathrm{NE}_{\frac{1}{4}} \mathrm{NW} \frac{1}{4}$, sec. 36, T. $1 \mathrm{~S} ., \mathrm{R} .14 \mathrm{~W}$. , Saline County. Reynolds Mining Co. 12-13-5l.

40. Bauxite, daily mine production. Harris mine, NE $\frac{1}{4} \mathrm{NW} \frac{1}{4}$, sec. 36, T. 1 S., R. 14 W., Saline County. Reynolds Mining Co. 12-14-51.

41. Bauxite, daile mine production. Harris mine, $N E \frac{1}{4} N W \frac{1}{4}$, sec. 36, T. 1 S., R. 14 W., Saline County. Reynolds Mining Co. 12-19-51.

42. Bauxite, daily mine production. Harris mine, $\mathrm{NE} \frac{1}{4} \mathrm{NW} \frac{1}{4}$, sec. 36, T. 1 S., R. 14 W., Saline County. Reynolds Mining Co. 12-30-51.

43. Bauxite, daily mine production. Harris mine, NE $\frac{1}{4} \mathrm{NW} \frac{1}{4}$, sec. 36, T. 1 S., R. 14 W., Saline County. Reynolds Mining Co. 12-31-51.

44. Bauxite, daily mine production (12-31-51), Bray mine, sec. 35, T. 1 S., R. 14 W., Saline County. Reynolds Mining Co.

45. Bauxitic clay, one-day withdrawal (12-19-51). Elrod-Harris low-grade pile, sec. 35 , T. I S., R. 14 W., Saline County, Reynolds Mining Co.

46. Bauxite. Monthly composite for January, 1952, metal-grade shipments by Alcoa from Arkansas. 
has been derived from alkalic rocks and which may therefore be expected to be high in niobium content. Among such localities are the following:

Foços da Caldas, Minas Gerais, Brazil. Ile de Los, French Guinea, French West Africa. Gold Coast, western Africa.

\section{Niobium in byproducts of bauxite plants}

As stated previously, no data are yet available as to the distribution of niobium among the minerals present in bauxite. However, it is highly improbable from geochemical considerations that it is present in high concentrations as a substituent in the aluminum oxide hydrates or ferric oxide hydrates that constitute the bulk of bauxite ore. Rather, niobium would be expected to be present in solid solution in the tatanium and zirconium minerals. If this is correct, it might reasonably be expected that niobium could be concentrated in some stage of the chemical processing of bauxite ore.

In brief, the treatment of bauxite, as carried out at the Hurricane Creek, Ark. plant of the Reynolds Metal Co., is as follows: The bauxite is digested in hot sodium hydroxide solution. The insoluble material is separated from it as coarse material ("black sand") and fine material ("red mud"). From the solution, $\mathrm{A}_{2} \mathrm{C}_{3} \cdot 3 \mathrm{H}_{2} \mathrm{O}$ is crystallized, leaving "spent liquor." The black sand is discharged into a special tailings pond. The red mud is mixed with $\mathrm{CaCO}_{3}$ plus $\mathrm{Na}_{2} \mathrm{CO}_{3}$ and sintered, after which it is leached to recover more alumina. The leached residue ("brown mud") is discharged into a tailings pond.

By analyzing samples obtained through the courtesy of Mr. W. W. Binford, superintendent of the Hurricane Creek plant of the Reynolds Metal Co., we have been able to follow the course of the niobium during the process. The analytical data are given in table 3; they show that niobium is concentrated in the material that is insoluble in $\mathrm{NaOH}$ solution.

The brown mud, although its niobium content is slightly higher than that of the black sand, is not a very attractive material on which to attempt further concentration because the material is so fine-grained. Work so far has therefore been confined to the black sand. A study by the U. S. Bureau of Mines (Calhoun, 1950) showed that titanium-rich and ironrich concentrates could be prepared by tabling and by magnetic separation. The data on these concentrates are given in table 4 . Through the courtesy of $\mathrm{Mr}$. Binford, samples of these concentrates were obtained by the Geological Survey and analyses for niobium are given in table 4.

The titanium-rich concentrate was further purified in our laboratory by Miss Jewell J. Glass by means of magnetic and heavy-mineral separations. Data on the fractions obtained, given in table 5 , show that the niobium content can be raised to over 0.8 percent. It is hoped that further work will permit the analysis of the individual pure minerals.

As a check, a black sand (No. 12 of table 3) was subjected to heavy-mineral and magnetic separations. The procedure was as follows: Approximately 300 grams was crushed to pass 80 -mesh. The material passing 270-mesh was not investigated further. The portion passing 80 -mesh and retained on 270 -mesh was separated twice in methylene iodide (sp gr 3.2). The heavy fraction was then divided into the following magnetic fractions: Magnetic to the hand magnet, magnetic at $0.1,0.2,0.3$, and 0.5 amperes and nonmagnetic at 0.5 amperes at a slope of $20^{\circ}$ towards the nonmagnetic side of a Franz Isodynamic Separator. The results, given in table 6 , agree in general with those of tables 4 and 5.

Comparable products from the East St. Louis, ill., plant of the Aluminum Company of America have not been studied. However, we have fractionated

Table 3.--Niobium content of products of treatment of Arkansas bauxite at the Hurricane Creek plant, Reynolds Metal Co.

\begin{tabular}{|c|c|c|c|}
\hline No. & Product & Percent $\mathrm{Nb}$ & Analyst \\
\hline $\begin{array}{l}1 \\
2 \\
3 \\
4 \\
5 \\
6 \\
7 \\
8 \\
9 \\
10 \\
11 \\
12 \\
13 \\
14 \\
15 \\
16 \\
17\end{array}$ & $\begin{array}{l}\mathrm{Al}_{2} \mathrm{O}_{3} \cdot 3 \mathrm{H}_{2} \mathrm{O} \\
\mathrm{Cal} \text { ined alumina } \\
\text { Spent liquor } \\
\text { Sinter filtrate- } \\
\text { Red mud- } \\
\text { Brown mud }\end{array}$ & $\begin{array}{l}<0.01 \\
<.01 \\
<.01 \\
.01 \\
.08 \\
.07 \\
.076 \\
.069 \\
.073 \\
.09 \\
.06 \\
.064 \\
.062 \\
.052 \\
.048 \\
.048 \\
.052\end{array}$ & $\begin{array}{l}\text { K. J. Murata } \\
\text { Do. } \\
\text { Do. } \\
\text { Do. } \\
\text { Do. } \\
\text { Do. } \\
\text { Do. } \\
\text { Do. } \\
\text { Do. } \\
\text { Do. } \\
\text { Do. } \\
\text { H.J. Rose, Jr. } \\
\text { Do. } \\
\text { Do. } \\
\text { Do. } \\
\text { Do. } \\
\text { Do. }\end{array}$ \\
\hline
\end{tabular}

${ }^{a}$ Samples of red mud from treatment of Surinam and Jamaica bauxite each contained 0.02 percent $\mathrm{Nb}$. 
Table 4.--Analyses of titanium- and iron-rich concentrates from black sands from the Hurricane Creek plant, Reynolds Metal Co.

\begin{tabular}{|c|c|c|c|c|c|c|c|}
\hline & \multicolumn{2}{|c|}{ Ti Concentrate ${ }^{1}$} & \multirow{2}{*}{$\frac{\text { Fe Concentrate }}{(a)}$} & & \multicolumn{2}{|c|}{ T1 Concentrate ${ }^{1}$} & \multirow{2}{*}{$\frac{\text { Fe Concentrate }}{2}$} \\
\hline & (a) & (b) & & & (a) & (b) & \\
\hline $\begin{array}{l}\mathrm{TiO}_{2} \\
\mathrm{Fe} \\
\mathrm{Mn}- \\
\mathrm{Al}_{2} \mathrm{O}_{3}-\cdots \\
\mathrm{SiO}_{2}-\cdots\end{array}$ & $\begin{array}{r}41.2 \\
20.1 \\
8.9 \\
9.4 \\
2.6\end{array}$ & $\begin{array}{r}39.9 \\
19.9 \\
--- \\
--- \\
-\cdots\end{array}$ & $\begin{array}{r}8.0 \\
46.5 \\
--- \\
8.9 \\
1.4\end{array}$ & $\begin{array}{l}\text { CaO } \\
\text { Ignition loss- } \\
\text { Percent } \mathrm{No}-\end{array}$ & $\begin{array}{c}0.6 \\
2.2 \\
30.67\end{array}$ & --- & $\begin{array}{l}0.5 \\
12.2 \\
30.032\end{array}$ \\
\hline
\end{tabular}

a. After Calhoun (1950). Analysis by U. S. Bureau of Mines.

b. Leonard Shapiro, U. S. Geol. Survey, analyst.

IThis concentrate was 3.4 percent by weight of the black sand.

2This concentrate was 4.5 percent by weight of the black sand.

3H. J. Rose, Jr. and Janet D. Fletcher, U. S. Geol. Survey, analysts.

a black sand kindly furnished by $\mathrm{Mr}$. Laurence Litchfield of Alcoa Mining Co. This was produced from an experimental Wilfley-table installation later discontinued (letter from Laurence Litchfield to M. Fleischer, January 21, 1952). Analyses on the fractions, given in table 7 , show that the material is similar to the titanium-rich concentrate from the Hurricane Creek plant (table 5) except that it contains much siderite and little magnetite.

\section{Niobium in titanium minerals}

Although the geochemical association of niobium with titanium has long been recognized and many analyses of titanium minerals in the literature show appreciable niobium contents, little attention has been paid to the variation of niobium content with the type of rock in which the titanium minerals occur. Determinations of the niobium content of the common titanium minerals are assembled in table 8 , omitting only the rarer silicates. Data on the latter are given by Fleischer and Harder (1945) and by Rankama (1948).

Many more analyses are needed on material of known paragenesis, but a few generalizations can be made from the data in table 8. It seems clear that minerals from alkalic rocks and from granitic pegmatites are highest in niobium and that those associated with anorthosites and gabbros are lowest. This is shown best by the data for ilmenite. The largest masses of titanium-rich rocks, such as the huge ilmenite-magnetite deposits associated with the anor thosite-gabbro of the Adirondacks and Quebec, are very low in niobium content; the ilmenite from the beach sands of Florida and India, presumably derived from crystalline rocks, have $\mathrm{Nb}$ contents ranging from 0.04 to 0.40 percent; and ilmenite from alkalic rocks is highest (up to 0.9 percent).

The few data available in table 8 indicate that when rutile and ilmenite occur together, rutile generally has the higher hiobium content. Of the 35 rutile samples listed in table 8,12 have $\mathrm{Nb}$ contents more than 1 percent. Most rutile, however, will probably be found to contain 0.05 to 0.3 percent $\mathrm{Nb}$, with samples of higher $\mathrm{Nb}$ content found in granitic pegmatites and alkalic rocks.

The 20 perovskite analyses listed in table 8 include 13 or 14 from alkalic rocks. Those highest in niobium occur in carbonatites associated with alkalic rocks.

\section{FOSSIBILITY OF RECOVERY OF NIOBIUM FROM ARKANSAS BAUXITE AND FROM TITANIUM MINERALS}

The data reported as the result of this work suggest the possibility that niobium may be obtained from three sources not now utilized:

1. As a byproduct from Arkansas bauxite.

2. From titanium minerals used in the manufacture of titanium metal.

3. From titanium minerals from alkalic rocks such as the carbonatites.

Table 5.--Analyses of fractions of titanium-rich concentrate referred to in table 4

[Separations' by Jewell, Glass]

\begin{tabular}{|c|c|c|c|}
\hline • & Percent of total & Percent $\mathrm{Mb}^{\mathrm{a}}$ & Percent $\mathrm{TiO}_{2}{ }^{\mathrm{b}}$ \\
\hline \multirow{3}{*}{$\begin{array}{l}\text { Original titanium-rich concentrate-- } \\
\text { Fractions: } \\
\text { Magnetite- } \\
\text { Calcite and quartz- } \\
\text { Ilmenite plus limonite } \\
\text { Mainly zircon, with some rutile, } \\
\text { sphene, ilmenite. }\end{array}$} & 100 & 0.67 & 39.9 \\
\hline & $\begin{array}{l}12.4 \\
10.5 \\
73.3 \\
3.8\end{array}$ & $\begin{array}{c}(c)^{.026} \\
.79-.86 \\
.87\end{array}$ & $\begin{array}{r}1.3 \\
46-50 \\
36\end{array}$ \\
\hline & 100.0 & -- & --- \\
\hline
\end{tabular}

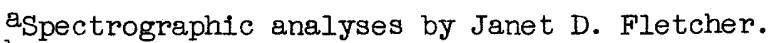

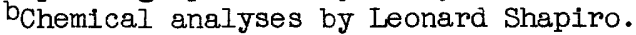

$\mathrm{c}_{\text {Not }}$ determined. 
Table 6.--Analyses of fractions of a black sand from bauxite

[Separations by Marie L. Lindberg; analyses by Janet D. Fletcher]

\begin{tabular}{|c|c|c|c|}
\hline Material & $\begin{array}{l}\text { Percent of } \\
\text { total }\end{array}$ & $\begin{array}{l}\text { Percent of } \\
-80,+270\end{array}$ & Percent $\mathrm{Nb}$ \\
\hline $\begin{array}{l}\text { Original black sand- } \\
\text { Minus } 270 \text {-mesh } \\
\text { Float in methylene iodide- } \\
\text { Sink in methylene iodide: }\end{array}$ & $\begin{array}{l}100 \\
24.7 \\
10.9\end{array}$ & $\begin{array}{r}--- \\
14.5\end{array}$ & $\begin{array}{c}0.064 \\
(1) \\
(1)\end{array}$ \\
\hline $\begin{array}{r}\text { Magnetic to hand magnetate } \\
0.1 \text { amp. } \\
.2 \text { amp. } \\
.3 \text { amp. } \\
.5 \text { amp. } \\
\text { Nonmagnetic at } 0.5 \text { amp. }\end{array}$ & $\begin{array}{r}38.8 \\
6.7 \\
4.4 \\
12.0 \\
2.1 \\
.4 \\
100.0\end{array}$ & $\begin{array}{r}51.5 \\
8.9 \\
5.8 \\
15.9 \\
2.8 \\
.5 \\
99.9\end{array}$ & $\begin{array}{l}.025 \\
.035 \\
.064 \\
.14 \\
.66 \\
.45\end{array}$ \\
\hline
\end{tabular}

${ }^{1}$ Not determined.

Froduction of bauxite from Arkansas in 1949 was 1,094,924 long tons of dried bauxite equivalent (Mote and Kurtz, 1951). Assuming that the average

Table 7.--Analyses of fractions of black sand from Wilfley table (Alcoa)

[Separations by Marie L. Lindberg; analyses by K. J. Murata]

\begin{tabular}{l|c|c}
\hline Material & $\begin{array}{c}\text { Percent } \\
\text { of sample }\end{array}$ & $\begin{array}{c}\text { Percent } \\
\mathrm{Nb}\end{array}$ \\
\hline Original black sand------ & 100 & --- \\
Mainly siderite--- & 55 & 0.06 \\
About 90 percent ilmenite-- & 32 & .57 \\
Ilmenite with much limonite & 3 & .16 \\
Zircon with some anatase & 10 & .08 \\
and rutile. & 10 & \\
\hline
\end{tabular}

content of $\mathrm{Nb}$ is 0.05 percent, this corresponds to 547.5 long tons or 1.2 million pounds of niobium-80 percent of the amount imported by the United States in the same year.

The data in table 3 show that niobium is concentrated in the red and brown muds and in the black sands. The data of table 4 to 7 show the niobium to be concentrated in the titanium-rich fraction of the black sands; it is probable that this is also true of the red and brown muds. These might, however, contain more rutile and sphene and less ilmenite than the black sands, but quantitative data are lacking. The problem of obtaining niobium from Arkansas bauxite thus appears to be one of treating a concentrate containing approximately 40 to 50 percent $\mathrm{TiO}_{2}$ and 0.5 to 0.9 percent $\mathrm{Nb}$.

Most of the ilmenite processed in the United States is used in the manufacture of $\mathrm{TiC}_{2}$ pigment. This involves solution of the ore in acid, followed by hydrolysis to precipitate titanium dioxide. It is probable that niobium accompanies the titanium in this precipitation and that its recovery would be very difficult. on the other hand, the production of titanium metal is increasing very rapidly. This process involves the chlorination of titanium-rich ore to form $\mathrm{TiCl}_{4}$. Since $\mathrm{TiCl}_{4}$ boils at $136^{\circ} \mathrm{C}$ and $\mathrm{NbC} 15$ at $243^{\circ} \mathrm{C}$, conditions are favorable for obtaining good separations, as recently demonstrated on a laboratory scale by Atkinson, Steigman, and Hiskey (1952). Further research on the process is obviously needed, as well as a study of the economic factors.

Research is also needed on the possibility of using rutile, brookite, or perovskite, such as that obtained from alkalic rocks. As readily seen from the data in table 8 , these minerals contain much higher $\mathrm{Nb}$ contents than the ilmenite concentrates from Arkansas bauxite, but they lack the advantage of known availability in large tonnages. The possibility of recovering niobium from perovskite-pyrochlore in alkalic rocks has been discussed for the deposits of the Kola Feninsula, U. S. S. R. (Eliseev and Nefedov (1940), Gerasimovsky (1939, 1940); for the deposits of the Kaiserstuhl, Baden, Germany (Leibrandt, 1948); and for the deposits of Tororol, Uganda (Hudson and Dunkin, 1951).

The Geological Survey is continuing its investigations of rutile, brookite, and perovskite at Magnet Cove, Ark., and of similar deposits elsewhere. It is to be hoped that metallurgical researches on the recovery of niobium from these titanium minerals will be carried out by other laboratories.

\section{LITERATURE CITED}

Ahrens, L. H., 1952, The use of ionization potentials, I, Ionic radii of the elements: Geochim. et Cosmochim. Acta, vol. 2, pp. 155-169.

Atkinson, R. H., Steigman, Joseph, and Hiskey, C. F., 1952, Analytical chemistry of niobium and tantalum: Anal. Chemistry, vol. 24, pp. 477-488.

Borovskiy, I. B. , and Blokhin, M. A., 1937, The analysis of materials by the X-ray spectroscopical method: Acad. sci. U. R. S. S. Bull., Sér. géol., no. 5, pp. 929-936.

Bykova, V. S., 1941, Chemical composition of the Lovazero loparite and a method for its analysis: Acad. sci. U. R. S. S. Comptes rendus, vol. 33, pp. $136-130$.

Calhoun, W. A., 1950, Titanium and iron minerals from black sands in bauxite: U. S. Bur. Mines Rept. Investigations $4621,16 \mathrm{pp}$.

Chernik, G. F., 1914, Chemical studies of minerals from Ceylon placers: Acad. Sci. St. Fetersburg Bull., 1914, pp. 41-51; Neues Jahrb. Mineral., Referate 1, 1915, pp. 36-40. 
Chernik, G. F., 1921, Chemical analysis of an ilmenorutile from the Urals: Acad. sci. U.R.S.S. Bull., vol. 15, pp. 425-428; Mineralog. Abstracts, vol. 2, pp. 405-406 (1925).

Clark,J. W., 1951, Minor metals: U. S. Bur. Mines, Minerals Year Book for 1949, pp. 1306-1308.

Crook, T. and Johnstone, S. J., 1912, Strueverite from the Federated Malay States: Mineralog. Mag., vol. 16, pp. 224-231.

Dieke, G. H., and Crosswhite, H. M., 1943, Use of iron lines as intensity standards: Opt. Soc. America Jour., vol. 33, pp. 425-434.

Edwards, A. B., 1940, A note on some tantalumniobium minerals from western Australia: Australasian Inst. Min. Metallurgy Froc., no. 120, pp. 731-744.

Eliseyev, Na A., and Nefedov, N. K., 1940, The loparite deposits of lujavrite: Froizvod. Sily Kol'skog Foluostrove 1940, no. 1, pp. 77-118; Chem. Abstracts, vol. 37, p. 1679 (1943).

Fleischer, Michael and Harder, J. C. , 1945, The geochemistry of columbium and tantalum: L. S. Geol. Survey Report to the Manhattan District, Feb. 1945, revised June 1946, and reproduced as MDDC-645, $27 \mathrm{pp}$.

Gerasimovskiy, V. I. , 1939, Fegmatites of the Lovazero alkaline massif: A kad. Nauk SSSR, Inst. Nauk Trudy, no. 18, Mineral. - Geokhim. Ser. 5, pp. $1-45$.

\section{0, Columbium and} tantalum in the U.S.S.R. A kad. Nauk SSSR, Inst. Geol. Nauk. Trudy, no. 39, Mineral. -Geokhim. Ser. 8, pp. 49-57.

Goldschmidt, V. M., 1937, The principles of distribution of chemical elements in minerals and rocks: Chem. Soc. London Jour., pp. 655-673.

Gordon, Mackenzie, Jr., and Murata, K. J., 1952, Minor elements in Arkansas bauxite: Econ. Geology, vol. 47, pp. 169-179.

Hauser, Otto, 1908 , Ueber den sogennanten Dysanalyt von Vogtsburg im Kaiserstuhl. Zeitschr. anorg. Chem., vol. 60, pp.237-241 (1908).

Hevesy, G. von, Alexander, E., and Würstlin, K., 1929, The abundance ratio $\mathrm{Nb} / \mathrm{Ta}$ in titanium minerals: Zeitschr. anorg. allgem. Chem., vol. 181, pp. $95-100$.

Hess, F. L., and Wells, R. C., 1911, An occurrence of strueverite: Am. Jour. Sci., 5th ser., vol. 31 , pp. 432-442.

Hudson, S. B., and Dunkin, H. H., 1951, Electrostatic concentration of pyrochlore from Tororo, Uganda: Ore Dressing Investigations, Commonwealth Sci. and Ind. Research Crg. and Mining Dept., Univ. Melbourne, Investig. no.400, pp. 1-11.

Knop, A., 1877, Dysanalyt, ein pyrochlorartiges Mineral. Zeitschr. Krist., vol. 1, pp. 284-296.
Kunitz, Wilhelm, 1936, The role of titanium and zirconium in rock-forming silicates: Neues Jahrb. Mineral., Geol., Beilage-Band 70, Abt. A, H 3, pp. 385-466.

Leibrandt, F, 1948, The occurrence of niobium minerals in the Kaiserstuhl. Mitteilungsblatt Badischen geol. Landesanstalt 1948, pp. 39-42.

Mar, F. W., 1890, So-called perofskite from Magnet Cove, Arkansas. Am. Jour. Sci., vol. 40, pp. 403-405.

Meigen, W., and Hügel, E., 1913, Ueber die chemische Zusammensetzung des Dysanalyts von Vogtsburg im Kaiserstuhl. Zeitschr. anorg. Chemie, vol. 82, pp. 242-248.

Morozewicz, J, 1930, Mariupolite and related rocks: Mineralog. petrog. Mitt., vol. 40, pp. 335-436.

Mote, R. H., and Kurtz, H. F. (1951). U. S. Bur. Mines, Minerals Yearbook for 1949, p. 171.

Myers, A. T. (1951). Improved cutting tool for spectroscopic electrodes. Anal. Chem., vol. 23, pp. 209-210.

Fanteleyev, F. G. (1938). Titanium, nioblum, and tantalum in the alkaline complex of the Il'menskiye Gory, in the Urals: Acad. sci. U. R. S. S. Bull., Sér. Géol., no. 5-6, pp. 827-836.

Frior, G. T., and Zambonini, F., 1908, Cn strueverite and its relation to ilmenorutile. Mineralog. Mag., vol. 15, pp. 78-89.

Rankama, Kalervo, 1948, On the geochemistry of niobium. Annales Acad. Sci. Fennicae, Ser. A, III, No. 13, pp. 1-57.

Sahama, T. G., (1946). On the chemistry of the mineral titanite. Comm. géol. Finlande Bull. 138, pp. 88-120.

Smith, Bracewell. (1946). The geology and mineral resources of British Guiana. Handbook of natural resources of British Guiana, sec. 4, pp. 18-40; Mineralog. Abstracts, vol. 10, p. 292 (1948).

Tavora, Elysiario and Scorza, E. F., 1948, Ccorrencia de rutilo columbiano no Brasil Ministerio Agric., Brazil, Div. geol. e mineral., Notas prelim. e estudos, no. 45, 1-60. from Colatina, Espirito Santo.

Ussing, N. V., 1912, Geology of the country around Julianehaab, Greenland Medd. om Gronland vol. 38 , pp. 1-426.

Yurk, Yu. Yu., and Breser, V. M., 1940, Geochemistry of rare elements in the granitic pegmatites of the western Azov seacoast region: J. Geol., Acad. Sci. Ukrain. S. S. R., vol. 6, no. 4, pp. 131-163; Chem. Abstracts, vol. 35, p. 416 (1941).

Yurk, Yu. Yu., and Tsarovskiy, I. D. (1940). Black ore minerals of the Mariupol' alkaline massif. J Geol. (Acad. Sci. Ukrain. S. S. R. Inst. Geol.) vol. 7, no. 1-2, pp. 151-162; Chem. Abs. , vol. 35, p. 3198 (1941). 
Table 8.--Niobium content of titanium minerals

\begin{tabular}{|c|c|c|c|c|}
\hline No. & $\begin{array}{l}\text { Percent } \\
\mathrm{Nb}\end{array}$ & Locality & Type of occurrence & Analyst \\
\hline
\end{tabular}

Rutile (including the variety ilmenorutile) $\left(\mathrm{TiO}_{2}\right)$

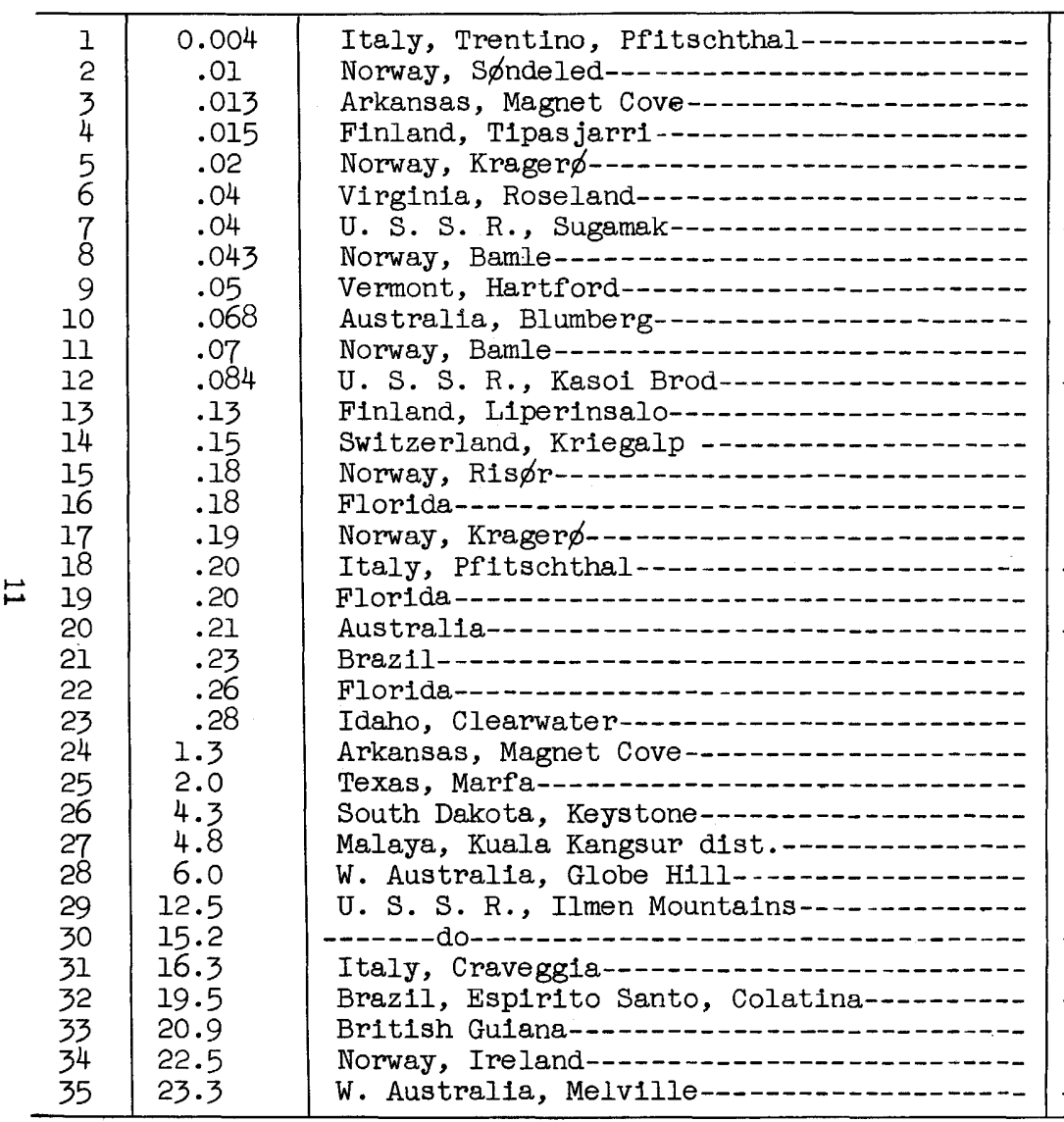

Nepheline syenite
Anorthosite

Rankarna (1948).

Hevesy and others (1929). Do.

Rankama (1948).

Hevesy and others (1929).

H. J. Rose, Jr.

Rankama (1948).

Do.

Hevesy and others (1929).

Rankama (1948).

Do.

Do.

Hevesy and others (1929).

Rankama (1948).

J. D. Fletcher.

Rankama (1948).

Hevesy and others (1929).

J. D. Fletcher.

Do.

Do

Do.

Do.

Do.

Hess and Wells (1911).

Crook and Johnstone (1912).

Edwards (1940).

Chernik (1921).

Prior and Zambonini (1908).

Do.

Tavora and Scorza (1948).

Smith (1946).

Prior and Zambonini (1908).

Edwards (1940).

Brookite $\left(\mathrm{TiO}_{2}\right)$

\begin{tabular}{l|c|c|}
\hline 36 & 0.01 & Sw1tzerland, Riederstobel- \\
37 & .023 & U. S. S. R., Urals \\
38 & .38 & Arkansas, Magnet Cove- \\
39 & 2.4 & -
\end{tabular}

Alpine cleft--..-

Nepheline syenite-

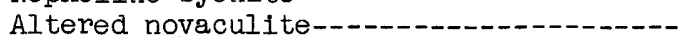

Hevesy and others (1929).

Rankama (1948).

Do.

K.J.Murata and E. L. Hufschmidt. 
Table 8.--Niobium content of titanium minerals--Continued

\begin{tabular}{|c|c|c|c|c|}
\hline No. & $\begin{array}{c}\text { Percent } \\
\mathrm{Nb}\end{array}$ & Locality & Type of occurrence & Analyst \\
\hline \multicolumn{5}{|c|}{ Anatase $\left(\mathrm{TiO}_{2}\right)$} \\
\hline $\begin{array}{l}40 \\
41 \\
42\end{array}$ & $\begin{array}{r}0.032 \\
.047 \\
1.8\end{array}$ & $\begin{array}{l}\text { Switzerland, Binnenthal } \\
\text { California, Cady Mountain }\end{array}$ & $\begin{array}{l}\text { Alpine cleft } \\
\text { Granite pegmatite }\end{array}$ & $\begin{array}{l}\text { Rankama (1948). } \\
\text { Do. } \\
\text { K. J. Murata. }\end{array}$ \\
\hline
\end{tabular}

Perovskite $\left(\mathrm{CaTiO}_{3}\right.$ ) (including the niobian variety

dysanalyte and the cerian variety loparite

\begin{tabular}{|c|c|c|}
\hline 43 & 0.006 & U. S. S. R., Urals, Achmatovsk- \\
\hline 44 & $<.01$ & 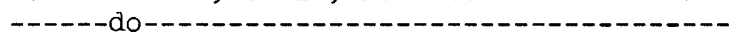 \\
\hline 45 & .47 & U. S. S. R., Kola Peninsula \\
\hline 46 & 3.1 & Arkansas, Magnet Cove \\
\hline 47 & 3.3 & 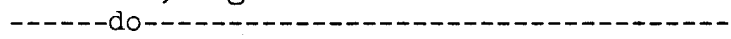 \\
\hline 48 & 3.4 & Germany, Kaiserstuhl-_. \\
\hline 49 & 5.1 & Arkansas, Magnet Cove-1- \\
\hline 50 & 5.6 & 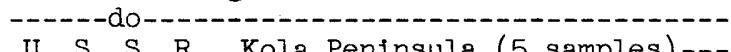 \\
\hline $\begin{array}{l}51 \\
52\end{array}$ & $\begin{array}{r}5.6-6.8 \\
1 \quad 11.3\end{array}$ & $\begin{array}{l}\text { U. S. S. R., Kola Peninsula (5 samples)-- } \\
\text { Germany, Kaiserstuhl }\end{array}$ \\
\hline 53 & 15.6 & Ceylon, Prov. Uva- \\
\hline 54 & 18.2 & Germany, Kaiserstuhl \\
\hline
\end{tabular}

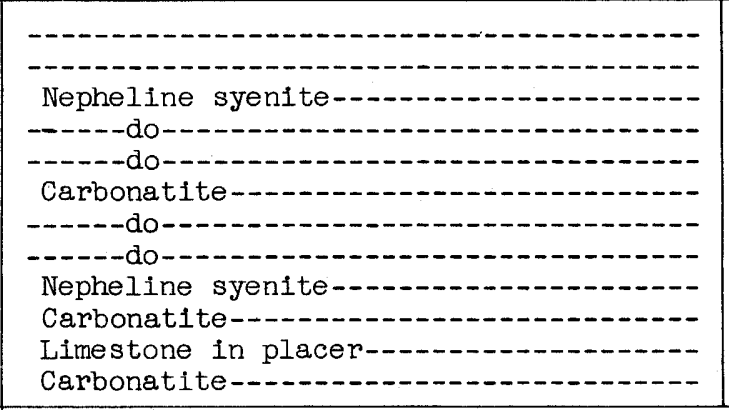

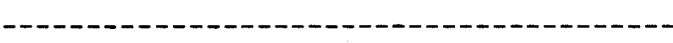

Carbonatite-ras

Carbonatite-co-co-

Carbonatite----

Carbonatite-........
Rankama (1948).

Hevesy and others (1929).

Rankama (1948).

Mar (1890).

Rankama (1948).

Houser (1908).

H. J. Rose, Jr.

K. J. Murata.

Bykova (1941).

Meigen and Hugel (1913).

Chernik (1914).

Meigen and Hugel (1913).

Ilmenite-magnetite ores

\begin{tabular}{l|l|l|}
\hline 55 & 0.0002 & Finland, Attu Parainen- \\
56 & .006 & Finland, Otanmaki- \\
57 & $<.01$ & New York, Lake Sanford (9 samples) \\
58 & $<.01$ & Quebec, Allark Lake (2 samples) \\
59 & $<.01$ & Costa Rica- \\
60 & .018 & Norway, Hitterb \\
61 & .039 & U. S. S. R., Ilmen Mountains \\
62 & .18 & U. S. S. R., Vuorikylä-
\end{tabular}

Amphibolite-1.Anorthosite-gabbro-_-_._-

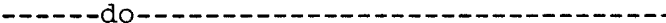
-

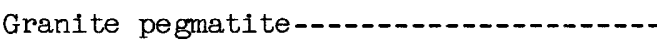
Alkalic rocks-_-_._-

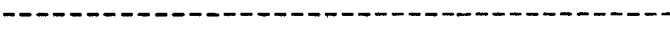

\section{Ilmenite $\left(\mathrm{FeTiO}_{3}\right)$}

\begin{tabular}{l|l|l|}
\hline 63 & 0.00002 & Norway, Egersund \\
64 & .0002 & South Africa- \\
65 & .0003 & U. S. S. R., Urals, Miask \\
66 & .001 & India- \\
67 & .005 & Norway, Blaaf jeld \\
68 & $\varsigma .01$ & New York, Adirondacks (4 samples) \\
69 & $<.01$ & Quebec, Baie St. Paul (5 samples) \\
70 & $<.01$ & North Carolina, Lenoir \\
71 & $<.01$ & Virginia, Piney River- \\
72 & $<.01$ & Virginia, Roseland-. \\
73 & $<.01$ & Norway (3 samples)
\end{tabular}

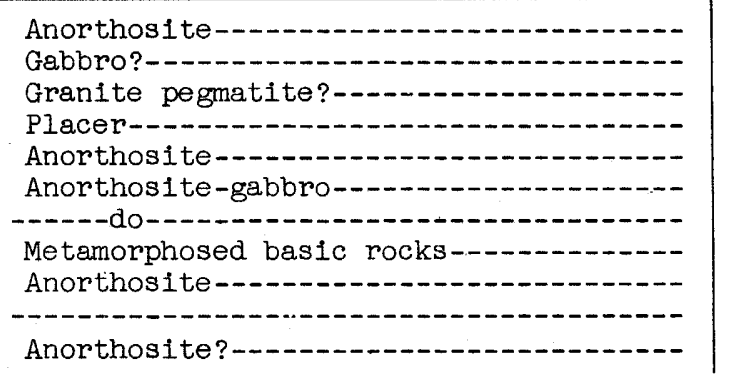

Rankama (1948).

Do.

E. L. Hufschmidt.

Do.

Rankama (1948).

Do.

Do.

Hevesy and others (1929). Do.

Do.

Do.

Rankama (1948).

J. D. Fletcher.

Do.
Do.
Do
Do
Do.




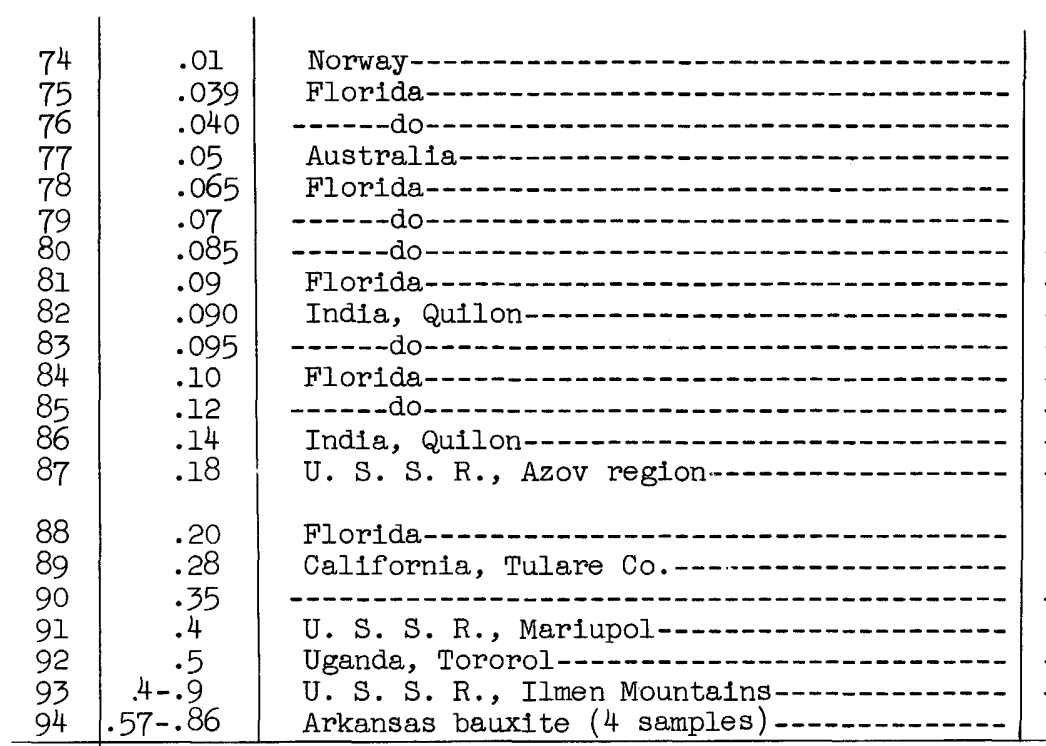

Sphene ( $\mathrm{CaTiSiO}_{5}$ )

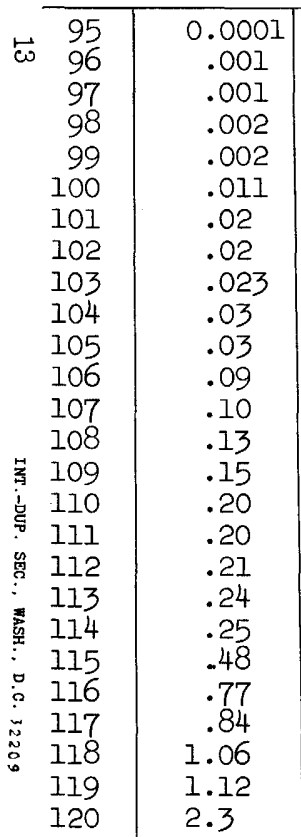

Norway, Krager $\phi-\cdots$ Switzerland, St. Gotthard-

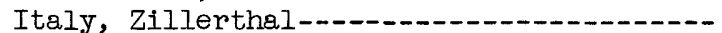

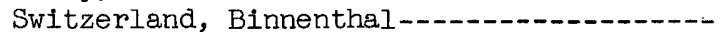

Norway, Arendal

Norway, Krager $\phi \ldots \ldots \ldots$

Norway, Sфndeled

U. S. S. R., Ura]s, Miask-

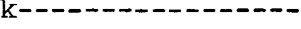

Norway, Arendal

Finland, Ylojarvi-..-.-

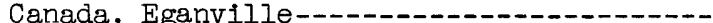

Canada, Pontiac Co.--_.-.--

Norway, Ris $\varnothing$

Finland, Iivaara-1..-

Sweden, Hajstorp

Germany, Aschaffenburg-

U. S. S. R., Transbeikal i Sviatoy Noss-

U. S. S. R., Kola Peninsula-_.-Finland, Parainen-1.-

U. S. S. R., Kola Peninsula-_.-...--

Norway, Krager $\phi-19$
U. S. S. R., Kola Peninsula-

U. S. S. R., Nuolainniemi, Core.......

U. S. S. R., Nuolainniemi, Shell_....-.
Placer--0-10Beach sands -

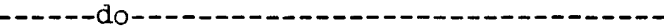

- - - - do----

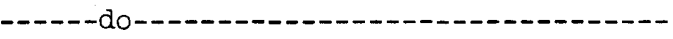

- - - - do--

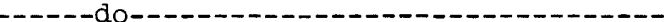

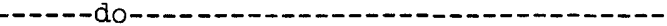

-

- - - - do-_- - - - do--

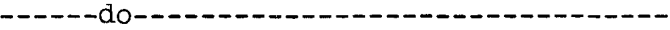
- - - - do-

-Beach sands, derived from granite pegmatite.

Beach sand--0.--

Granite pegmatite---_-

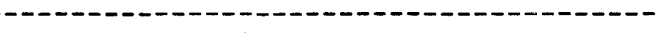

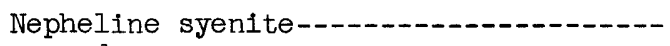
-

Bauxite--.----_-

\section{(including keilhauite variety)}

- - - Granite pegmatite-...Grendte peget Gabbro

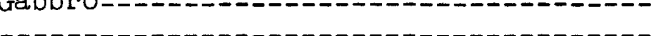

Gabbro-

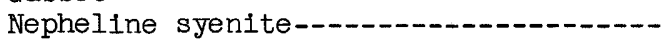
Nepheline syenite-co-ros Nepheline syenite-

Iimestone-

Nepheline syenite-

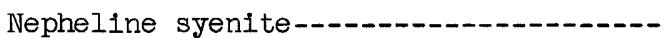
Granite pegmatite--o- -do--
Hevesy and others (1929).

J. D. Fletcher.

Do.
Do.
Do.
Do.
Do.
Do.
Do.
Do.
Do.
Do.
Do.

Yurk and Bresser (1940).

J. D. Fletcher.

Do.

Borowsky and Blochin (1937).

Yurk and Bresser (1940).

H. J. Rose, Jr.

Panteleev (1938)

J. D. Fletcher.

Hevesy and others (1929).

Do.

Do.

Do.

Do.

Do.

Sahama (1946).

Hevesy and others (1929).

Rankama (1948).

Sahama (1946).

Hevesy and others (1929).

Rankama (1948).

$$
\begin{aligned}
& \text { Do. } \\
& \text { Do. } \\
& \text { Do. } \\
& \text { Do. }
\end{aligned}
$$

Sahama (1946)

Rankama (1948).

Sahama (1946).

$$
\text { Do. }
$$

Rankama (1948).

Sahama (1946).

Do.

Do. 
